\title{
Re: Metastatic deaths in retinoblastoma patients treated with intraarterial chemotherapy (ophthalmic artery chemosurgery) worldwide
}

\author{
Sameh E. Soliman ${ }^{1,2^{*} \mathbb{D}}$, Helen Dimaras ${ }^{1}$, Brenda Gallie ${ }^{1}$ and Furqan Shaikh ${ }^{3}$
}

\section{Dear Editor,}

We read with interest the recent Commentary by Abramson and colleagues, entitled "Metastatic deaths in retinoblastoma patients treated with intraarterial chemotherapy (ophthalmic artery chemosurgery) worldwide" [1]. The authors retrospectively collected data on all patients treated with intra-arterial chemotherapy (IAC) between May 2006 and November 2016 from six retinoblastoma centers, in order to determine the rate of metastatic death in patients who received IAC. The six centers collectively treated 1177 eyes of 1139 patients. Three patients died from metastatic retinoblastoma, all from a single center in Argentina, and all associated with refusal of enucleation or poor follow-up. The authors concluded that the rate of metastatic death after IAC conducted at centers with expertise is low, at $<1 \%$. The authors are to be congratulated for their efforts in assembling such a large pooled database of patients with a rare disease, and for determining this reassuring result. However, we would like to point out some shortcomings of their publication.

An important goal of treating retinoblastoma is to prevent tumor spread or metastasis which is a concern with IAC as a treatment for retinoblastoma as it provide good local control without systemic control [2]. Treatment of metastases is an immense burden with the morbidity and lifelong consequences of intensive chemotherapy, autologous stem cell transplantation, and possibly external

\footnotetext{
*Correspondence: samehelsayedsoliman@yahoo.com

${ }^{1}$ The Department of Ophthalmology and Vision Sciences, The Hospital for Sick Children, 555 University Avenue, Room 7265, Toronto, ON M5G $1 \times 8$, Canada

Full list of author information is available at the end of the article
}

beam radiation therapy. In developing countries where stem cell transplant is not available, metastatic retinoblastoma is largely incurable [3]. The Commentary does not mention the rate of metastases in 1139 patients and focuses on the single outcome of metastatic deaths. Death is, of course, the most important outcome in any trial, but is not the only one of importance.

Both metastases and deaths occur after some time from therapy, and under-detection of delayed events affects the validity of cancer studies. This is especially true for retrospective studies from tertiary or elite referral centers, which often receive international or distant patients for treatment, who then return home and are not longitudinally followed and might have died unreported [4]. Statistical methods, such as Kaplan-Meier analysis where patients are censored at date last seen can adjust for this differential follow-up effect. Was the follow-up duration and quality sufficient to detect most events? How do the centers retrieve data from lost follow-up patients? The Commentary does not provide any time-to-event analysis, nor even a simple median follow-up time.

The duration of follow-up is crucial and longer followup often reveals additional events. The Commentary itself provides a noteworthy example of this very point. It states that "a year ago our centers in New York, Philadelphia, Argentina and Switzerland reported on 634 cases with only one metastatic death." [5] In the Commentary, they report three metastatic deaths from the center in Argentina, suggesting that two additional deaths occurred in 18 months.

The IAC literature has been reported across several scores of publications, each with a different subset of patients, different measurements, and different outcomes [5-17]. This multiplicative piecemeal reporting creates 
shortcomings in the scientific evidence and inconsistency of numbers presented. A representative example is in the Commentary. The authors state that their six centers treated 1177 eyes of 1139 patients, representing all patients treated with IAC in the included time period. By mathematical necessity, this would mean that no more 38 patients were treated bilaterally. However, the authors from one center have separately published [16] the results of 60 patients treated with IAC bilaterally in 120 eyes from within the same period.

We close by stating that these points should not be seen as controversial, provocative, or adversarial. There is really no controversy in stating that studies should have important outcomes, adequate follow-up, accurate detection, and consistent information. These are bedrock principles and required standards of all clinical studies.

\section{Authors' contributions}

Concept: SS, HD, BG, FS; Design: SS, HD, BG; FS, Revision: SS, HD, BG, FS. All authors read and approved the final manuscript.

\section{Author details}

${ }^{1}$ The Department of Ophthalmology and Vision Sciences, The Hospital for Sick Children, 555 University Avenue, Room 7265, Toronto, ON M5G 1X8, Canada. ${ }^{2}$ Ophthalmology Department, Faculty of Medicine, University of Alexandria, Alexandria, Egypt. ${ }^{3}$ The Division of Hematology/Oncology, Department of Pediatrics, The Hospital for Sick Children, Toronto, ON, Canada.

\section{Competing interests}

The authors declare that they have no competing interests.

\section{Availability of data and materials}

Not applicable.

\section{Consent for publication}

Not applicable.

\section{Ethics approval and consent to participate} Not applicable.

\section{Funding}

Not applicable.

\section{Publisher's Note}

Springer Nature remains neutral with regard to jurisdictional claims in published maps and institutional affiliations.

Received: 14 January 2018 Accepted: 21 May 2018

Published online: 29 May 2018

\section{References}

1. Abramson DH, Shields CL, Jabbour P, Teixeira LF, Fonseca JRF, Marques $M C P$, et al. Metastatic deaths in retinoblastoma patients treated with intraarterial chemotherapy (ophthalmic artery chemosurgery) worldwide. Int J Retina Vitreous. 2017;3:40.
2. Yousef YA, Soliman SE, Astudillo PP, Durairaj P, Dimaras H, Chan HS, et al. Intra-arterial chemotherapy for retinoblastoma: a systematic review. JAMA Ophthalmol. 2016;134(6):584-91.

3. Dunkel IJ, Chan HS, Jubran R, Chantada GL, Goldman S, Chintagumpala $\mathrm{M}$, et al. High-dose chemotherapy with autologous hematopoietic stem cell rescue for stage $4 \mathrm{~B}$ retinoblastoma. Pediatr Blood Cancer. 2010;55(1):149-52.

4. White A, Gallie BL. Life before eye: implications for the whole child and family of attempted eye salvage for unilateral and severe bilateral retinoblastoma. 46th World Congress of the International Society of Paediatric Oncology. 2014.

5. Abramson DH, Shields CL, Munier FL, Chantada GL. Treatment of retinoblastoma in 2015: agreement and disagreement. JAMA Ophthalmol. 2015;133(11):1341-7.

6. Abramson DH, Dunkel IJ, Brodie SE, Kim JW, Gobin YP. A phase I/II study of direct intraarterial (ophthalmic artery) chemotherapy with melphalan for intraocular retinoblastoma initial results. Ophthalmology. 2008;115(8):1398-404.

7. Abramson DH, Dunkel IJ, Brodie SE, Marr B, Gobin YP. Bilateral superselective ophthalmic artery chemotherapy for bilateral retinoblastoma: tandem therapy. Arch Ophthalmol. 2010;128(3):370-2.

8. Abramson DH, Dunkel IJ, Brodie SE, Marr B, Gobin YP. Superselective ophthalmic artery chemotherapy as primary treatment for retinoblastoma (chemosurgery). Ophthalmology. 2010;117(8):1623-9.

9. Gobin YP, Dunkel IJ, Marr BP, Brodie SE, Abramson DH. Intra-arterial chemotherapy for the management of retinoblastoma: four-year experience. Arch Ophthalmol. 2011;129(6):732-7.

10. Abramson DH, Marr BP, Brodie SE, Dunkel I, Palioura S, Gobin YP. Ophthalmic artery chemosurgery for less advanced intraocular retinoblastoma: five year review. PLoS ONE. 2012;7(4):e34120.

11. Abramson DH, Marr BP, Dunkel IJ, Brodie S, Zabor EC, Driscoll SJ, et al. Intra-arterial chemotherapy for retinoblastoma in eyes with vitreous and/ or subretinal seeding: 2-year results. Br J Ophthalmol. 2012;96(4):499-502.

12. Marr BP, Brodie SE, Dunkel IJ, Gobin YP, Abramson DH. Three-drug intra-arterial chemotherapy using simultaneous carboplatin, topotecan and melphalan for intraocular retinoblastoma: preliminary results. $\mathrm{Br} \mathrm{J}$ Ophthalmol. 2012;96(10):1300-3.

13. Francis JH, Gobin YP, Dunkel IJ, Marr BP, Brodie SE, Jonna G, et al. Carboplatin $+/$ - topotecan ophthalmic artery chemosurgery for intraocular retinoblastoma. PLoS ONE. 2013;8(8):e72441.

14. Abramson DH, Fabius AW, Issa R, Francis JH, Marr BP, Dunkel IJ, et al. Advanced unilateral retinoblastoma: the impact of ophthalmic artery chemosurgery on enucleation rate and patient survival at MSKCC. PLOS ONE. 2015:10(12):e0145436.

15. Francis JH, Abramson DH, Gobin YP, Marr BP, Tendler I, Brodie SE, et al. Efficacy and toxicity of second-course ophthalmic artery chemosurgery for retinoblastoma. Ophthalmology. 2015;122(5):1016-22.

16. Abramson DH, Marr BP, Francis JH, Dunkel IJ, Fabius AW, Brodie SE, et al. Simultaneous bilateral ophthalmic artery chemosurgery for bilateral retinoblastoma (Tandem Therapy). PLoS ONE. 2016;1 16):e0156806.

17. Abramson DH, Daniels AB, Marr BP, Francis JH, Brodie SE, Dunkel IJ, et al. Intra-arterial chemotherapy (ophthalmic artery chemosurgery) for group D retinoblastoma. PLoS ONE. 2016;11(1):e0146582.

Ready to submit your research? Choose BMC and benefit from:

- fast, convenient online submission

- thorough peer review by experienced researchers in your field

- rapid publication on acceptance

- support for research data, including large and complex data types

- gold Open Access which fosters wider collaboration and increased citations

- maximum visibility for your research: over 100M website views per year

At BMC, research is always in progress.

Learn more biomedcentral.com/submissions 